\title{
The seedpod gum of Parkia pendula (Fabaceae) as a deadly trap for vertebrates
}

\author{
Daniel Piechowski ${ }^{1}$ * \\ Gerhard Gottsberger ${ }^{2}$ \\ ${ }^{1}$ Institute of Systematic Botany and Ecology, Ulm University \\ Albert-Einstein-Allee 11, 89081 Ulm, Germany \\ ${ }^{2}$ Botanical Garden and Herbarium, Ulm University \\ Hans-Krebs-Weg, 89081 Ulm, Germany \\ *Corresponding author \\ danielpiechowski@web.de
}

Submetido em 07/07/2008

Aceito para publicação em 29/10/2008

\section{Resumo}

A goma da vagem de Parkia pendula: uma armadilha fatal para vertebrados. O uso da goma de vagens de Parkia pendula para capturar aves foi mencionado uma única vez na literatura. No presente trabalho apresentamos a observação de um indivíduo do lagarto Tropidurus hispidus que morreu após ser colado no substrato pela goma de P. pendula de um fragmento de Mata Atlântica no Estado de Pernambuco. Esta observação evidencia a enorme capacidade adesiva desta goma, que pode ser considerada um perigo potencial para pequenos vertebrados.

Unitermos: Mata Atlântica, Mimosoideae, Parkia pendula, goma de vagem, Tropidurus hispidus

\section{Abstract}

In the literature, it has been mentioned that the seedpod gum of Parkia pendula is used for catching birds. Here we present an observation of a Tropidurus hispidus individual that died after being glued to the substrate by the gum of $P$. pendula in the Atlantic Forest of Pernambuco State. This observation proves the enormous gluing performance of this gum, which can be considered as a potential danger for small vertebrates.

Key words: Atlantic Forest, Mimosoideae, Parkia pendula, seedpod gum, Tropidurus hispidus

Parkia pendula (Willd.) Walp. (Fabaceae, Mimosoideae) is the most widely distributed Neotropical Parkia species, occurring in lowland terra-firme forests from Honduras in Central America southwards to the Atlantic Forest of the Brazilian State of Espírito Santo (Hopkins, 1986). This tree species is a typical (Ferraz et al., 2004) and abundant (Guedes, 1998) species of the
Atlantic Forest endemism center of Pernambuco (Silva and Casteleti, 2003). Its density in this region is much higher than in Amazonian forests (2-3/ha (Piechowski and Gottsberger, 2008) vs. 0.1/ha (Peres, 2000)). The adult trees are easily recognizable by their very distinctive flattened crown (Ribeiro et al., 1999). The mass-flowering species (Hopkins, 1984) presents its red 
capitula on long axes underneath the crowns (Hopkins, 1986), which makes it one of the most beautiful trees of the Amazon basin (Ribeiro et al., 1999).

Parkia pendula is known to be pollinated by bats with Phyllostomus discolor being the main pollinator (Carvalho, 1961; Hopkins, 1984; Piechowski 2007a). Besides its pollination ecology, P. pendula is also known for its unique seedpod gum. The pods of $P$. pendula (as well as that of its close congener P. paraensis Ducke) secrete large quantities $(6.34 \pm 2.79 \mathrm{~g}$ fresh weight per pod; Piechowski, unpublished data) of a unique sticky amber-colored gum, into which the seeds are released after dehiscence of the pods (Hopkins and Hopkins, 1983). This gum is a very attractive source of protein, carbohydrates, calcium, and magnesium (Anderson and Pinto, 1985; Peres 2000) for parrots and primates (summarized by Peres, 2000). Most probably, the animals swallow the seeds while feeding on the gum and defecate them thereafter, as already proven for Parkia panurensis H.C. Hopkins (Knogge et al., 2003; Knogge and Heymann, 2003).

The stickiness of the seedpod gum is most likely caused by its high content of polysaccharides of the main constituent sugars galactose and arabinose (Anderson and Pinto, 1985; Peres, 2000). A combination of these carbohydrates with the gum's $2.2-3.1 \%$ protein content (Anderson and Pinto, 1985; Peres, 2000) to glycoproteins is unknown, but very likely, since these compositions are often found to be the basis of naturally occurring glues (Onusseit, 2004). Such organic glues are similar to synthetic glues in their 'gluing-performance' (Onusseit, 2004).

The observation reported here was made within the study on the reproductive ecology, seedling performance, and population structure of $P$. pendula in the Atlantic Forest fragment 'Piedade' in northeastern Brazil (Piechowski, 2007b). This fragment (approximately $306 \mathrm{ha}$ ) is located on a sugarcane plantation approx. $40 \mathrm{~km}$ north of Recife, in Pernambuco State.

On 19 December 2003, an individual of Tropidurus hispidus Spix (Tropiduridae) was found to be glued to a P. pendula seedpod by the seedpod gum (Figure 1) on the forest floor underneath a fruiting $P$. pendula tree in the western edge zone of the 'Piedade' forest (S07 $50^{\prime} 35.7^{\prime}$ ', W35 00 '09.0"). The lizard's extremities and its tail were covered with the sticky seedpod gum, causing its total immobility. A visit on the morning of the following day showed that ants were feeding on the lizard's eyes. This was the cause of its death.

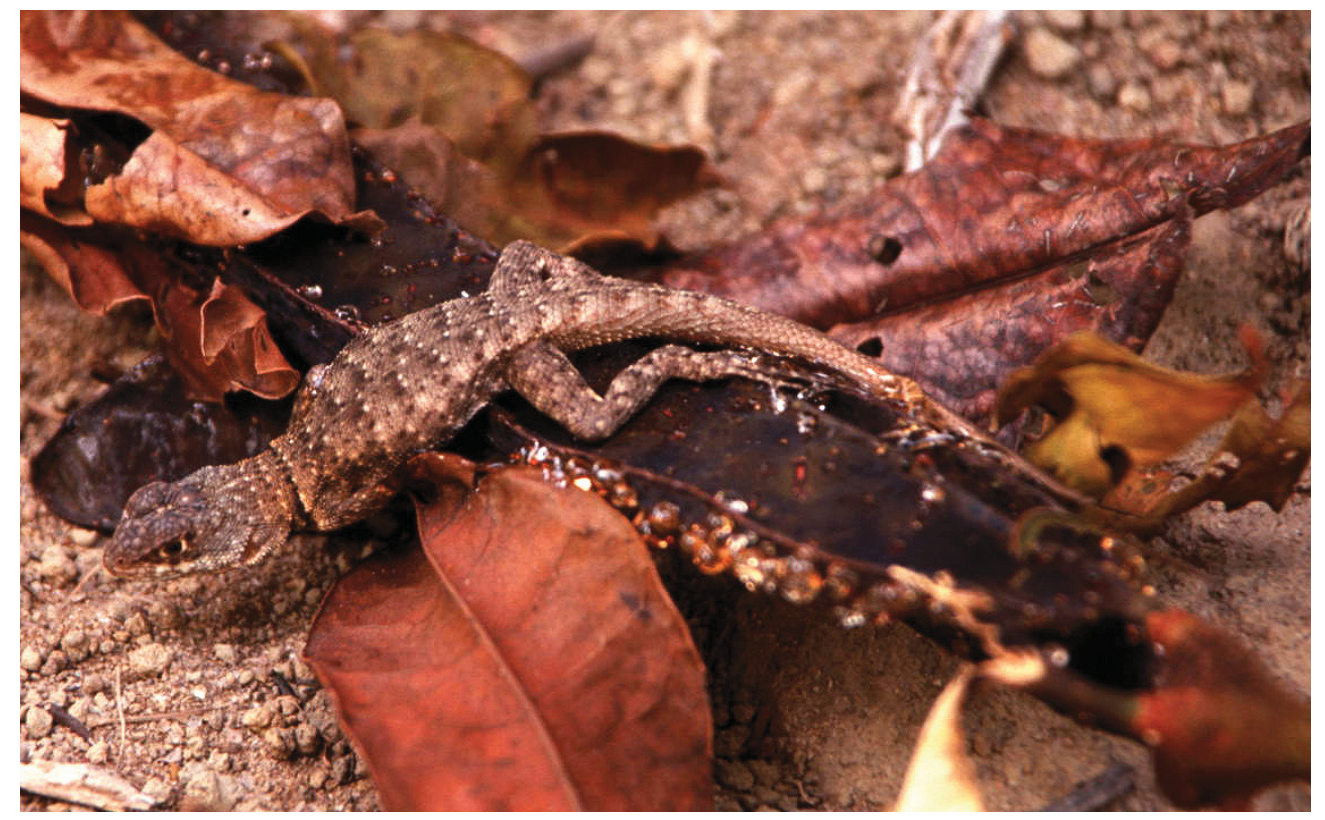

FIGURE 1: Tropidurus hispidus glued to the seedpod gum of Parkia pendula on the forest floor of the Atlantic Forest fragment 'Piedade', Municipality of Igarassu, Pernambuco, Brazil. Size of the seedpod approx. $25 \mathrm{~cm}$. 
This observation is to our best knowledge the first proof of the gum's capability to glue small vertebrates (body length of adult $T$. hispidus: $70-129 \mathrm{~mm}$, weight: 10.8-62.5g (Vitt 1993)) to the substrate after Hopkins' (1986) report in her monograph about the Neotropical Parkia species that "the gum [of P. pendula] is used for catching birds".

\section{Acknowledgments}

Contribution of the project "Sustainability of remnants of the Atlantic rainforest in Pernambuco and its implications for conservation and local development", a Brazilian-German scientific cooperation within the program "Science and Technology for the Atlantic Rainforest" funded by CNPm (590039/2006-7) and BMBF (01 LB 0203 A1). The Usina São José S.A. / Grupo Cavalcanti Petribú kindly allowed access to their properties and supported fieldwork logistically. Many thanks to Ednilza Maranhão dos Santos, Universidade Federal Rural de Pernambuco (UFRPE), for the identification of the lizard based on the photography. Leonhard Krause, Ulm University, kindly translated the abstract. Two anonymous reviewers improved the manuscript with their comments.

\section{References}

Anderson, D. M. W.; Pinto, G. L. 1985. Gum polysaccharides from three Parkia species. Phytochemistry, 24 (1): 77-79.

Carvalho, C. T. 1961. Sobre os hábitos alimentares de Phillostomídeos (Mammalia, Chiroptera). Revista de Biología Tropical, 9 (1): 53-60

Ferraz, E. M. N.; Araújo, E. L.; Silva, S. I. 2004. Floristic similarities between lowland and montane areas of Atlantic coastal forest in northeastern Brazil. Plant Ecology, 174 (1): 59-70.

Guedes, M. L. S. 1998. A vegetacão fanerogâmica da Reserva Ecológica de Dois Irmãos. In: Machado, I. C.; Lopes, A. V. \& Porto, K. C. (Eds). Reserva Ecológica de Dois Irmãos: Estudos em um remanescente de Mata Atlântica em área urbana (Recife - Pernambuco - Brasil). Editora Universitária da UFPE, Recife, Brazil, p.157-172.
Hopkins, H. C. F. 1984. Floral biology and pollination ecology of the Neotropical species of Parkia. Journal of Ecology, 72 (1): $1-23$

Hopkins, H. C. F. 1986. Parkia (Leguminosae: Mimosoideae). Flora Neotropica 43, New York Botanical Garden, New York, USA, $124 \mathrm{pp}$.

Hopkins, H. C. F.; Hopkins, M. J. G. 1983. Fruit and seed biology of the Neotropical species of Parkia. In: Sutton, S. L.; Whitmore, T. C. \& Chadwick, A. C. (Eds). Tropical Rain Forest: Ecology and Management. Blackwell, Oxford, London, Edinburgh, UK, p.197-209.

Knogge, C.; Herrera, E. R. T.; Heymann, E. W. 2003. Effects of passage through tamarin guts on the germination potential of dispersed seeds. International Journal of Primatology, 24 (5): 1121-1128.

Knogge, C.; Heymann, E. W. 2003. Seed dispersal by sympatric tamarins, Saguinus mystax and Saguinus fuscicollis: diversity and characteristics of plant species. Folia Primatologica, 74 (1): 3347.

Onusseit, H. 2004. Klebstoffe der Natur: Anwendungen und Perspektiven für die Technik. Biologie in unserer Zeit, 34 (5): $307-$ 314.

Peres, C. A. 2000. Identifying keystone plant resources in tropical forests: the case of gum from Parkia pods. Journal of Tropical Ecology, 16 (2): 287-317.

Piechowski, D. 2007a. Bat visits and changes in floral nectar during anthesis of Parkia pendula (Mimosaceae). Phyton (Horn), 46 (2): 203-204.

Piechowski, D. 2007b. Reproductive ecology, seedling performance, and population structure of Parkia pendula in an Atlantic Forest fragment in northeastern Brazil. Doctoral thesis, Ulm University, Germany, 153pp.

Piechowski, D.; Gottsberger, G. 2008. Edge effects on germination, seedling establishment, and population structure of Parkia pendula in an Atlantic Forest fragment, NE Brazil. Bioremediation, Biodiversity and Bioavailability, 2 (1): 56-61.

Ribeiro, J. E. L. S.; Hopkins, M. J. G.; Vicentini, A.; Sothers, C. A.; Costa, M. A. S.; Brito, J. M.; Souza, M. A. D.; Martins, L. H. P.; Lohmann, L. G.; Assunção, P. A. C. L.; Pereira, E. C.; Silva, C. F.; Mesquita, M. R.; Procópio, L. C. 1999. Flora da Reserva Ducke: Guia de Identificação das Plantas Vasculares de uma Floresta de Terra-Firme na Amazônia Central. INPA-DFID, Manaus, Brazil, 816pp.

Silva, J. M. C.; Casteleti, C. H. M. 2003. Status of the biodiversity of the Atlantic Forest of Brazil. In: Galindo-Leal, C. \& Câmara. I. G. (Eds). The Atlantic Forest of South America - Biodiversity status, threats, and outlook. Island, Washington, Covelo, London, USA, p.43-59.

Vitt, L. J. 1993. Ecology of isolated open-formation Tropidurus (Reptilia: Tropiduridae) in Amazonian lowland rain forest. Canadian Journal of Zoology, 71 (12): 2370-2390. 